\title{
Pemijahan Ikan Cupang Alam (Betta Channoides) Induk Alam (G0) Secara Berpasangan Dan Pengamatan Umur Matang Gonad Pertama Kali Keturunan Generasi Pertama (G1)
}

\section{Spawning of Snakehead Betta (Betta channoides) Wild Caught Broodstock (G0) in Pairs and Observation of First Time Gonad Maturity of First Breed Generation (G1)}

\author{
Asep Permana ${ }^{1 *}$, Agus Priyadi ${ }^{1}$, Ahmad Musa ${ }^{1}$, Bastiar Nur ${ }^{1}$, Sawung \\ Cindelaras $^{1}$, Sulasy Rohmy ${ }^{1}$ dan Siti Zuhriyyah Musthofa ${ }^{1}$ \\ ${ }^{1}$ Balai Riset Budidaya Ikan Hias, Depok, Jl. Perikanan Raya No.13, Pancoran Mas, Kec. \\ Pancoran Mas, Kota Depok, Jawa Barat 16436 \\ Corresponding author: asep_aa37@yahoo.co.id
}

Submitted: 01 August 2021 Revised: 11 October 2021 Accepted: 14 October 2021 Publish: 30 October 2021

\begin{abstract}
Abstrak
Ikan cupang alam (Betta channoides) merupakan ikan asli dan endemik dari Kalimantan Timur. Ikan ini mempunyai warna yang indah dan menarik sebagai komoditas ikan hias. Ikan ini bisa memijah alami baik secara berpasangan maupun secara massal. Sejauh ini data reproduksi induk dari alam (G0) dan umur matang gonad pertama kali ikan generasi pertama (G1) belum diketahui. Penelitian ini bertujuan untuk mengetahui data reproduksi dari pemijahan secara berpasangan dan pertumbuhan serta umur matang gonad generasi pertama. Untuk melihat data reproduksinya dalam penelitian ini dilakukan pemijahan secara berpasangan (1:1). Hasil anakan dari pemijahan ini kemudian dipelihara dan dibesarkan dengan tujuan untuk melihat pertumbuhan dan umur matang gonad. Parameter yang akan diamati pada penelitian ini adalah data reproduksi: jumlah anakan, jumlah larva, sintasan larva dan benih, pertumbuhan dan umur matang gonad pertama anakan (G1). Hasil penelitian menunjukkan bahwa data reproduksi ikan $B$ chanoides yang dipijahkan secara berpasangan menghasilkan larva sebanyak $61 \pm 7,00$ ekor, sintasan larva sampai pemeliharaan umur 30 hari sebesar $88 \pm 2,65 \%$, sintasan benih sampai pemeliharaan umur 120 hari sebesar $71,33 \pm 3,21 \%$. Pertumbuhan panjang mutlak dari larva sampai ukuran induk umur 120 hari sebesar 34,02 mm dan anakan generasi pertama memerlukan waktu untuk menjadi induk selama 120 hari atau 4 bulan.

Kata Kunci: pemijahan berpasangan, sintasan, pertumbuhan, umur matang gonad, generasi pertama, $B$ cahnoides
\end{abstract}

Abstract

Snakehead Betta (Betta channoides) is native and endemic fish from East Borneo. As one of ornamental fish commodity, it has beautiful and very attractive coloration. This fish can spawn either pairs or mass. As far as we know that the reproductive data of wild broodstock $\left(\mathrm{G}_{0}\right)$ and first-time maturity of first breed generation $\left(\mathrm{G}_{1}\right)$ are still unknown. The aim of this research is to determine the data of spawning in pairs, growth, and maturity of first generation $\left(\mathrm{G}_{1}\right)$ gonad. Spawning was carried in pairs ( 1 female:1male) to collect reproductive data. the resulting fish fry from the spawning then reared and observed of growth and gonad maturity. The observation parameters are numbers of fish fry and larvae, survival rate of fry and larvae, growth, and maturity of first generation $\left(\mathrm{G}_{1}\right)$. Reproductive data of spawning in pairs occurred $61 \pm 7.00$ larvae with survival rate to 30 days was $88 \% \pm 2.65 \%$, and 120 days of rearing was $71.33 \pm 3.21 \%$. Growth rate from larvae to broodstock size occurred in 120 days with length about $34.02 \mathrm{~mm}$ and the time needed for first generation of fry to become adult was 120 days or in 4 month.

Keywords: Spawning, pairs, survival rate, growth rate, first time maturation, First generation, Betta channoides 


\section{PENDAHULUAN}

Ikan cupang alam (Betta channoides) merupakan ikan asli dan endemik dari Kalimantan Timur. Ikan ini merupakan salah satu cupang alam yang cukup populer karena warnanya yang cukup menarik dan mempunyai kepala seperti ular. Jantan berwarna biasanya lebih cerah warnanya merah kecoklatan dengan adanya garis putih dibagian sirip, sementara betinanya berwarna lebih pucat (Tan \& Ng., 2006; www.fishbase.com,

2020;

Seriuoslyfish, 2020). Dalam konteskontes cupang hias yang diselenggarakan oleh International Betta Congress (IBC), B. channoides ini dikelompokkan ke dalam kategori wild betta - small mouthbrooder atau berkembang biak dengan mengerami telur dan larvanya dalam mulut. Waktu inkubasi di mulut berkisar antara 10 15 dengan rata-rata 12 hari dan setelah itu anaknya dibiarkan bebas. Pemijahan biasanya diinisiasi oleh ikan betina dan anakan yang dihasilkan antara 3 - 40 ekor (Tan \& Ng., 2006).

Upaya budidaya ikan ini sudah dilakukan oleh Balai Riset Budidaya Ikan Hias (BRBIH) Depok sejak 2019. Hasil penelitian menunjukkan bahwa ikan ini dapat memijah secara alami baik itu secara berpasangan atau massal. Keberhasilan ini sangat bermanfaat terutama untuk pengembangan budidayanya. Strategi pengembangan budidayanya perlu didukung oleh data reproduksi seperti: fekunditas dan sintasan larva, serta data pertumbuhan dan umur yang diperlukan anakannya (G1) sampai menjadi induk kembali.
Tujuan penelitian ini dilakukan untuk mendapatkan data reproduksi induk alam (G0) dari pemijahan secara berpasangan dan pertumbuhan serta umur anakan generasi pertama (G1) ikan cupang alam (B chanoides) sampai menjadi induk.

\section{BAHAN DAN METODE}

\section{Waktu dan Tempat penelitian}

Penelitian dilakukan mulai dari bulan Januari-November 2019 dan bertempat di Balai Riset Budidaya Ikan Hias, Depok.

\section{Rancangan Penelitian}

Penelitian menggunakan rancangan deskriptif dan terdiri dari beberapa tahap kegiatan yaitu:

Pemeliharaan ikan uji dan pematangan gonad

Ikan uji berupa induk $B$. chanoides berasal dari Kalimantan yang sudah diadaptasi terlebih dahulu. Jumlah ikan uji sebanyak 10 pasang (10 jantan : 10 betina) dengan panjang $4-5 \mathrm{~cm}$ dan bobot 6-8 g. Ikan uji dipelihara secara terpisah antara jantan dan betina menggunakan dua buah styrofoam box. Ikan uji diberi pakan berupa Moina sp, Culex sp dan bloodworm secara bergantian tiap harinya dengan frekuensi satu hari sekali. Pemberian pakan untuk Moina sp, Culex sp secara ad libitum sedangkan bloodworm secara ad satiation. Tahapan pemeliharaan dan pematangan gonad ini dilakukan selama 2 bulan sampai didapat induk yang matang gonad dan siap dipijahkan.

Pemijahan

Setelah induk matang gonad, kemudian induk dipijahkan secara 
berpasangan $(1: 1)$ dalam wadah berupa akuarium ukuran $40 \times 25 \times 20 \mathrm{~cm}$, tinggi air $15 \mathrm{~cm}$ dan volume air $15 \mathrm{~L}$ dengan sistem pemeliharaan secara stagnan dan ditambah aerasi. Ikan yang dipijahkan sebanyak tiga pasang, dengan media shelter berupa potongan paralon untuk tempat berlindung. Selain itu diberikan juga daun ketapang satudua lembar agar media pemeliharaan mirip dengan habitatnya yaitu perairan dengan $\mathrm{pH}$ agak asam. Selama pemijahan ikan diberi pakan seperti pada tahap pematangan gonad. Untuk menjaga kualitas air, dilakukan pergantian air total setiap dua mingu sekali dengan air yang sudah diendapkan. Pengamatan pemijahan dilakukan setiap hari untuk melihat kapan ikan mulai kawin. Hal ini penting untuk menentukan masa pengeraman agar nantinya tepat dalam waktu pemanenan larva.

\section{Pemanenan larva}

Panen larva dilakukan pada hari ke8 setelah induk memijah, panen larva dilakukan dengan metode pengocokan larva dari mulut induk jantan yang dilakukan dengan membuka mulut jantan di dalam air sampai semua larva keluar. Setelah semua larva keluar, induk dikembalikan ke wadah pemeliharaan.

\section{Pemeliharaan larva sampai jadi induk}

Larva yang didapat dari masingmasing pasangan pemijahan kemudian dipelihara dengan tahapan sebagai berikut:

1) Pemeliharaan 1 bulan pertama: larva dipelihara dalam toples plastik volume 10 liter, dengan sistem stagnan. Media pemeliharaan ditambahkan methylene blue secukupnya untuk mencegah serangan jamur. Pakan yang diberikan berupa nauplii artemia sebagai pakan awal selama satu minggu. Pemberian pakan awal dilakukan pada hari ke empat setelah pemanenan larva ketika kuning telur sudah habis. Minggu kedua, larva sudah mulai bisa diberi pakan Moina sp yang halus, mimggu ketiga sampai umur satu bulan sudah diberi pakan Moina sp biasa. Pemberian pakan dilakukan sedikit-sedikit terlebih dahulu khususnya pada saat awal-awal makan. Setelah larva mulai makan dengan normal, pemberian pakan dilakukan secara ad libitum. Pergantian air dilakukan dua minggu sekali sebanyak 50\% menggunakan air dari tandon yang sudah diendapkan.

2) Pemeliharaan bulan kedua sampai jadi induk (umur 4 bulan): setelah larva berumur satu bulan, kemudian anakan ikan dipindah ke wadah akuarium ukuran $80 \times 40 \times 25 \mathrm{~cm}$ dengan tinggi air $15 \mathrm{~cm}$. Pada tahap pemeliharaan kedua ini larva sudah menjadi benih dan pakan yang diberikan berupa Moina sp secara ad libitum dan Tubifex secara ad satiation pada bulan kedua-ketiga, serta bloodworm secara ad satiation dan Culex sp secara ad libitum pada bulan keempat. Wadah pemeliharaan dilengkapi potongan paralon sebagai shelter atau tempat berlindung dan diberi daun ketapang dua-tiga lembar. Pergantian air dilakukan dua minggu sekali sebanyak 30-50\% 
Journal of Aquaculture Science

DOI: https://doi.org/10.31093/joas.v6i2.197
October 2021 Vol 6 (2) : 122-129

Online pada http://joas.co.id menggunakan air dari tandon yang sudah diendapkan.

\section{Parameter yang diamati}

Parameter yang diamatai dalam penelitian ini terdiri dari jumlah anakan yang di erami oleh induk jantan saat sedang pemanenan. Selanjutnya, sintasan larva dan benih yang ditentukan berdasarkan perhitungan menurut Efendi (1997) menggunakan rumus berikut:

$$
\mathrm{SR}=\frac{N t}{N o} \times 100 \%
$$

Keterangan:

$\mathrm{SR}=\operatorname{sintasan}(\%)$

$\mathrm{Nt}=$ jumlah ikan yang pada akhir pengamatan (ekor)

$\mathrm{No}=$ jumlah ikan yang ditebar pada awal pengamatan (ekor)

Disisi lain, laju pertumbuhan yang diamati adalah pertumbuhan panjang total, pengukuran dilakukan pada hari ke-1,6,22, 60 dan 120 hari pemeliharaan setelah menetas. Lebih dari itu, kami juga menetukan umur matang gonad anakan (G1) menentukan secara definitif tanda-tanda matang gonad. Dimana perut gendut dan terdapat telur di gonadnya (untuk betina), sedangkan jantan, warnanya sudah cerah kemerahan (Kusrini dkk, 2011). Analisis deskriptif dilakukan untuk menentukan hasil perlakuan dan menarik kesimpulan dengan referensi terkait yang relevan.

\section{HASIL DAN PEMBAHASAN}

Reproduksi B chanoides induk alam (GO)

Berdasarkan hasil pengamatan dari pemijahan tiga pasang ikan cupang alam $B$ chanoides secara berpasangan, data reproduksinya dapat dilihat pada Tabel 1 di bawah ini. Hasil pemijahan secara berpasangan pada induk $B$ chanoides menghasilkan anakan dengan rata-rata $61 \pm 7,00$ ekor (Tabel 1). Jumlah anakan sebanyak ini sesuai dengan hasil penelitian Priyadi $d k k$ (2019) tetapi lebih banyak dari yang dilaporkan (Tan \& Ng., 2006) yaitu sekitar 30 - 40 ekor. Jumlah anakan yang lebih banyak ini diduga karena teknik panen yang dilakukan melalui bantuan pengocokan dan dilakukan pada umur 8 hari setelah memijah, namun perlu kajian lebih lanjut. Keberhasilan ikan ini hidup, tumbuh dan memijah secara maksimal di lingkungan budidaya menunjukkan bahwa ikan ini sudah terdomestikasi dengan baik (Effendi, 2004). Ikan ini juga termasuk ikan yang cukup mudah dalam pemijahannya, terlihat dari hasil penelitian bahwa ikan ini bisa memijah secara alami baik secara massal maupun berpasangan. Larva yang dihasilkan kemudian dipelihara sampai menjadi induk baru generasi pertama (G1).

Tabel 1. Data Reproduksi $B$ chanoides induk alam (G0) hasil pemijahan berpasangan: jumlah anakan. sintasan larva umur 30 hari dan umur 120 hari (4 bulan).

\begin{tabular}{cccc}
\hline No Pasangan Induk & $\begin{array}{c}\text { Jumlah anakan } \\
\text { (ekor) }\end{array}$ & $\begin{array}{c}\text { Sintasan larva sampai } \\
\text { umur 30 hari (\%) }\end{array}$ & $\begin{array}{c}\text { Sintasan benih sampai } \\
\text { umur 120 hari (4 bulan) } \\
(\%)\end{array}$ \\
\hline Pasangan induk 1 & 54 & 85 & 75 \\
Pasangan induk 2 & 68 & 90 & 70 \\
Pasangan induk 3 & 61 & 89 & 69 \\
Rata-rata & $61 \pm 7,00$ & $88 \pm 2,65$ & $71,33 \pm 3,21$ \\
\hline
\end{tabular}


Pada tahap pemeliharaannya dibagi dalam dua tahap seperti disebutkan dalam metode. Sintasan larva dalam pemeliharaan tahap pertama sebesar 88 $\pm 2,65 \%$ sedangkan sintasan benih sampai induk dalam pemeliharaan tahap kedua sebesar $71,33 \pm 3,21 \%$. Nilai sintasan dalam pemeliharaan larva dan benih ikan ini tergolong tinggi, yang artinya larva ikan ini cukup mudah dalam menerima pakan awal yang merupakan titik kritis dalam pembenihan ikan. Mudahnya larva ikan ini dalam menerima pakan awal dikarenakan ukuran bukaan mulutnya yang cukup besar dan mampu memangsa pakan alami berupa nauplii artemia. Faktor lain yang juga mendukung tingginya nilai sintasan benih ikan ini adalah tidak mudahnya ikan ini terserang penyakit. Berikut adalah beberapa kegiatan selama penelitian yaitu: tahapan pemijahan, pengeraman, pemanenan, pemeliharaan larva dan benih yang dihasilkan sampai menjadi induk G1 (Gambar 1).

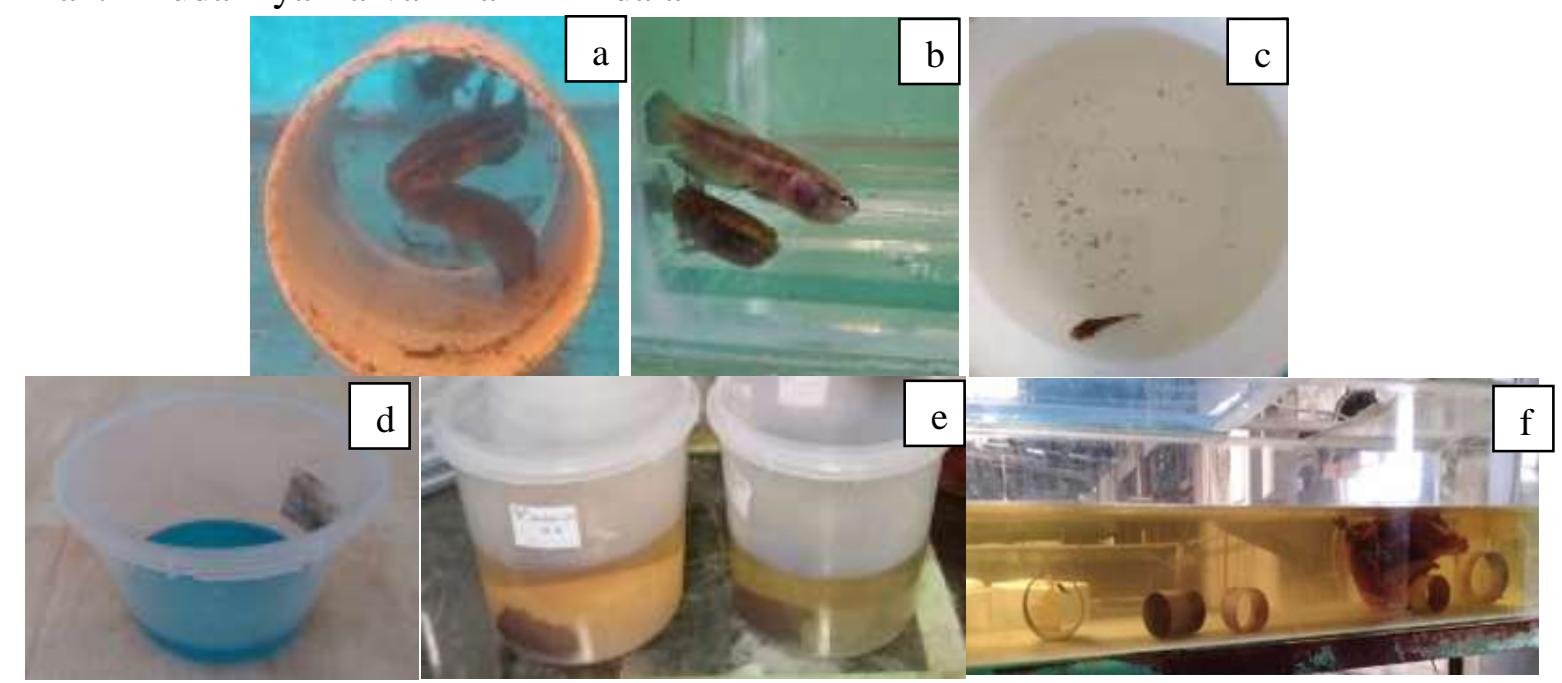

Gambar 1. a) tingkah laku pemijahan, b) pengeraman telur di mulut induk jantan, c) larva yang baru dipanen dari mulut induk jantan, d) wadah pemeliharaan larva sesaat baru dipanen sampai kirakira umur seminggu atau sampai habis kuning telurnya, e) wadah pemeliharaan larva lanjutan sampai umur satu bulan, f) wadah pemeliharaan benih setelah umur sebulan sampai empat bulan (sampai menjadi induk).

\section{Pertumbuhan dan umur anakan (G1)}

Pada pemeliharaan larva sampai menjadi induk generasi pertama (G1) dilakukan pengamatan pertumbuhan (panjang total) dan juga umur ikan (hari). Data pertumbuhan dan umur ikan dapat dilihat pada (Gambar 2) di bawah ini. Panjang larva pada saat baru dipanen adalah 4,33 $\pm 0,17 \mathrm{~cm}$, hari keenam atau ketika larva sudah mulai makan 5,64 $\pm 0,07 \mathrm{~cm}$. Perlu diketahui bahwa pada saat panen larva dari mulut induk jantan, diduga larva suah menetas kira-kira dua hari di dalam mulut induk jantan. Hal ini diketahui dari lama waktu antara saat memijah dengan waktu pemanenan larva yaitu 8 hari dan juga kondidi larva pada saat dipanen yang sudah aktif bergerak. Perkiraan waktu atau lama proses pengeraman telur sampai menetas selama 6 hari mengacu pada ikan cupang alam $B$ rubra (Permana $d k k, 2020)$. Faktor lain 
yang menguatkan dugaan ini adalah panjang larva pada saat baru dipanen yaitu $4,33 \pm 0,17 \mathrm{~cm}$, ini lebih panjang dibanding larva $B$ rubra yang baru menetas yaitu 3,45 mm (Permana $d k k$, 2020).

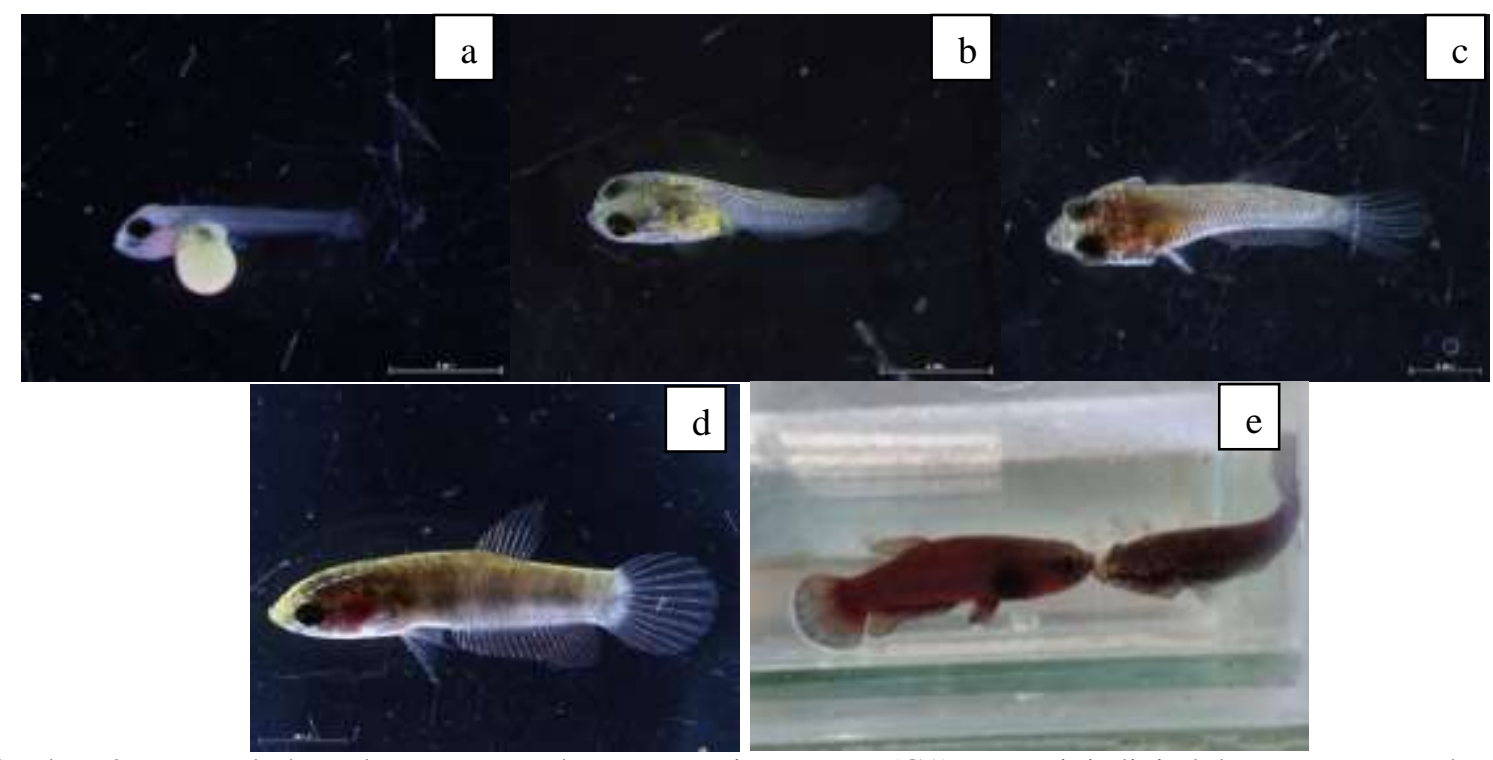

Gambar 2. Pertumbuhan dan umur anakan generasi pertama (G1) sampai jadi induk matang gonad pertama kali : a) larva umur satu hari setelah dipanen, b) 6 hari setelah dipanen, c) 22 hari setelah dipanen, d) 60 hari setelah dipanen (sudah menjadi benih), e) 120 hari setelah dipanen (sudah menjadi induk).

Pada hari keenam setelah dipanen atau 8 hari setelah menetas, larva sudah bisa makan nauplii artemia. Hal ini sesuai dengan ikan cupang alam $B$ rubra dimana larvanya mulai makan pada hari ketujuh setelah menetas (Permana $d k k, 2020)$. Pada hari ke-22 setelah panen atau 24 hari setelah menetas, larva sudah cukup besar yaitu $11,20 \pm 0,69 \mathrm{~cm}$ dan hampir menjadi benih walaupun belum sempurna seperti induknya. Perkembangannya untuk menjadi benih yang depinitif atau sempurna mirip dengan induknya diperkirakan masih perlu waktu beberapa hari lagi dan memerlukan pengamatan ontogeny lanjutan untuk memastikannya. Jika mengacu pada ikan $B$ rubra, waktu untuk menjadi benih yang definitif adalah 39 hari setelah menetas (Permana $d k k, 2020$ ). Hal ini didukung dengan data pada pengamatan umur 60 hari dimana ukuran benih mencapai $23,79 \pm 1,53 \mathrm{~cm}$ dan sudah depinitif. Bisa dipastikan bahwa umur untuk mencapai menjadi benih definitifnya sebelum 60 hari. 


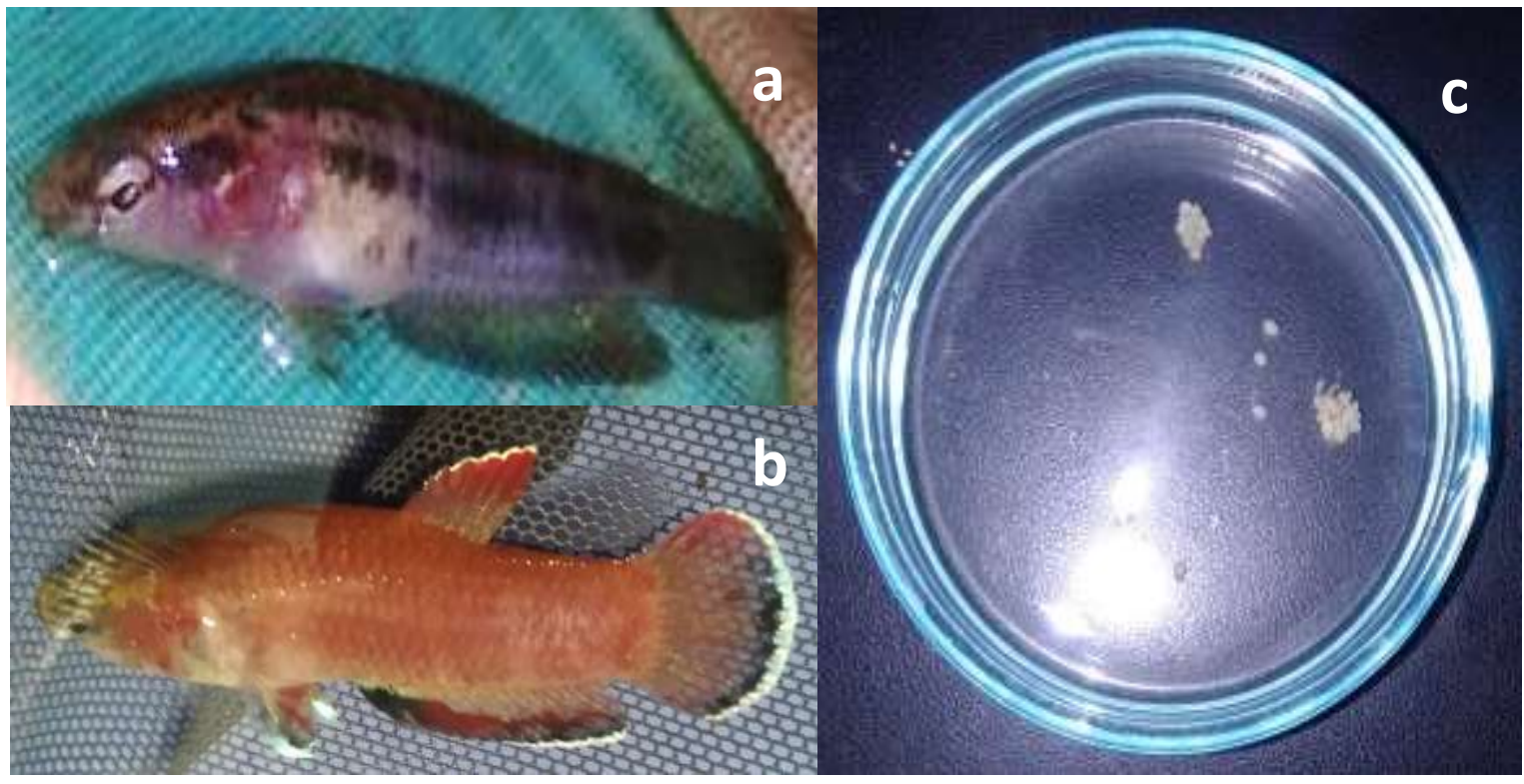

Gambar 3. Induk G1 matang gonad pertama kali, a) betina dan b: jantan, c) telur yang dihasilkan

Setelah definitif, kemudian benih dilanjutkan dipelihara dan pada pengamatan umur 120 hari ukuran sudah mencapai $38,35 \pm 2,00 \mathrm{~cm}$, benih sudah menunjukkan tanda-tanda kematangan gonad untuk pertama kali. Seperti terlihat pada (Gambar 3a), terlihat bahwa induk betina perutnya sudah gendut dan lembek, dan pada (Gambar 3b), terlihat induk jantan warnanya sudah cerah kemerahan, hal ini sesuai dengan pernyataan (Kusrini dkk., 2011). Untuk memastikan apakah benar - benar sudah matang, induk betina kemudian dibedah dan hasilnya terdapat telur di bagian gonadnya (Gambar 3c). Telur yang dihasilkan berwarna kuning keemasan dan butiran telur sudah dapat dipisahkan dengan diameter 1,32-1,40 $\mathrm{mm}$. Kriteria ini menunjukkan telur sudah dalam kondisi matang, hal ini sesuai penelitian Purnomo (2019). Data ini membuktikan bahwa pada umur 120 hari (4 bulan) anakan $B$ chanoides sudah bisa menjadi induk generasi pertama (G1), hal ini didukung hasil penelitian Kusrini $d k k$ (2011) dan Satyani (2003).

\section{KESIMPULAN}

Hasil penelitian menunjukkan bahwa data reproduksi ikan $B$ chanoides induk alam (G0) yang dipijahkan secara berpasangan menghasilkan larva sebanyak $61 \pm 7,00$ ekor, sintasan larva sampai pemeliharaan umur 30 hari sebesar $88 \pm 2,65 \%$, sintasan benih sampai pemeliharaan umur 120 hari sebesar $71,33 \pm 3,21 \%$. Pertumbuhan panjang mutlak dari larva sampai ukuran induk umur 120 hari sebesar 34,02 mm dan anakan generasi pertama memerlukan waktu untuk menjadi induk selama 120 hari.

\section{DAFTAR PUSTAKA}

Effendie, M.I. (1997). Biologi perikanan. Yogyakarta: Yayasan Pustaka Nusatama, $163 \mathrm{hlm}$.

Effendi, I. (2004). Pengantar Akuakultur. Penebar Swadaya, Jakarta 
Journal of Aquaculture Science

DOI: https://doi.org/10.31093/joas.v6i2.197

Fishbase, (2020). Betta channoides. http://fishbase.org/summary/Bettachannoides.htm. Diakses pada Juli 2020.

Kusrini, E., Sudarto dan R.V. Kusumah. (2011). Aspek biologi dan reproduksi ikan cupang alam (Betta bellica) dan potensi budi dayanya, Prosiding Seminar Nasional Ikan VI, 197-200.

Priyadi, A., A. Permana., I. Ardi., dan B. Nur. (2019). Domestikasi ikan hias Beta chanoides dalam sistem terkontrol sebagai upaya mempertahankan diversifikasi species di alam. Prosiding Seminar Nasional Biologi 4. UIN Sunan Gunung Djati. Bandung, 618-623.

Permana, A., E. Kusrini., A. Priyadi., dan S. Cindelaras. (2020). Perkembangan embrio dan larva pada domestikasi ikan cupang (Betta rubra Perugia, 1893),
Jurnal Riset Akuakultur, 15 (1), 2020, 19-29.

Purnomo, D. (2019). Aspek biologi reproduksi ikan cupang alam (Betta imbellis) di perairan umum waduk Fakultas Perikanan dan Kelautan Universitas Riau. Jurnal Online Mahasiswa (JOM) Fakultas Perikanan dan Ilmu Kelautan.

Satyani, D. (2003). Pengaruh umur induk ikan cupang (Betta splendens Regan) dan jenis pakan terhadap fekunditas dan produksi larvanya. Jurnal Penelitian Perikanan Indonesia 9(4): 13-18.

Seriuoslyfish, (2020). http://www.seriouslyfish.com/species/bet ta-channoides/. Diakses pada Juli 2020.

Tan, H. H. and P. K. L. Ng. (2006) Ichthyological Exploration of Freshwaters 17(2): 97-114. 